\title{
ANALISIS MUTU DAN ORGANOLEPTIK SIRUP EKSTRAK DAUN SELEDRI (APIUM GRAVEOLENS L.)
}

\author{
Adita Silvia $^{1)}$, Peppy Oktaviani ${ }^{2)}$ \\ ${ }^{1), 2)}$ Program Studi Farmasi Sekolah Tinggi Ilmu Kesehatan Harapan Bangsa Purwokerto \\ 1) aditasilvia@ @hb.ac.id, ${ }^{2)}$ peppyoktaviani@ shb.ac.id
}

\begin{abstract}
Abstrak
Tanaman seledri (Apium graveolens L.) telah lama dimanfaatkan sebagai bahan pengobatan tradisional sebagai antihipertensi oleh masyarakat Indonesia. Penelitian ini bertujuan untuk menentukan pengaruh variasi penambahan ekstrak daun seledri pada pembuatan pangan fungsional dalam bentuk sirup dari ekstrak daun seledri (Apium graveolens L.) terhadap penilaian organoleptik dan mutu sediaan sirup. Penelitian ini menggunakan Rancangan Acak Lengkap (RAL) yang terdiri dari 5 jenis perlakuan dan masingmasing perlakuan diulang sebanyak 3 kali. Variasi penambahan ekstrak daun seledri sebagai berikut: $(\mathrm{M} 0)=$ $0 \%$ (kontrol), (M1) = 0,33\% (0,55 g), (M2) = 0,39\% (0,65 g), (M3) =0,51\% (0,85 g) dan (M4) =0,6\% (1 g). Hasil penelitian menunjukkan bahwa ekstrak daun seledri memiliki aktivitas antioksidan dengan nilai IC50 sebesar 98,24 $\mu \mathrm{g} / \mathrm{mL}$ dan positif (+) mengandung flavonoid. Penambahan ekstrak daun seledri pada sirup berpengaruh sangat nyata terhadap organoleptik (aroma dan rasa), $\mathrm{pH}$ hari ke-7 dan viskositas, serta semua sirup homogen. Perlakuan yang paling disukai panelis adalah perlakuan M1 (0,33\%) dengan skor penilaian terhadap aroma sebesar 4,03 (suka) dan rasa 3,93 (suka) dan telah sesuai dengan SNI. Sedangkan perlakuan yang agak disukai panelis adalah perlakuan M4 $(0,6 \%)$ dengan skor penilaian terhadap aroma sebesar 3,24(agak suka) dan rasa 2,87 (agak suka) namun telah sesuai dengan SNI. Semakin sedikit penambahan ekstrak daun seledri, sirup semakin disukai oleh panelis.
\end{abstract}

Kata kunci : seledri, formulasi, sirup

\begin{abstract}
Celery plants (Apium graveolens L.) have long been used as ingredients of traditional medicine as antihypertensive by the people of Indonesia. This study aims to determine the effect of variations in the addition of celery leaf extract on the manufacture of functional food in the form of syrup from celery leaf extract (Apium graveolens L.) on organoleptic assessment and the quality of syrup preparations. This study used a Completely Randomized Design (CRD) consisting of 5 types of treatment and each treatment was repeated 3 times. Variation of addition of celery leaf extract as follows: $(\mathrm{MO})=0 \%$ (control), $(\mathrm{MI})=0.33 \%$ $(0.55 \mathrm{~g}),(\mathrm{M} 2)=0.39 \%(0.65 \mathrm{~g}),(\mathrm{M} 3)=0.51 \%(0.85 \mathrm{~g})$ and $(\mathrm{M} 4)=0.6 \%(1 \mathrm{~g})$. The results showed that celery leaf extract had antioxidant activity with IC50 values of $98.24 \mu \mathrm{g} / \mathrm{mL}$ and positive $(+)$ containing flavonoids. The addition of celery leaf extract to syrup has a very significant effect on organoleptics (aroma and taste), 7th day $\mathrm{pH}$ and viscosity, and all homogeneous syrups. The most preferred treatment panelist was treatment M1 (0.33\%) with a scoring score of 4.03 (likes) and a taste of 3.93 (likes) and according to SNI. While the panelists preferred the treatment of M4 (0.6\%) with a scoring score of 3.24 (rather like) and flavor of 2.87 (rather like) but according to SNI. The fewer additions of celery leaf extract, the syrup is increasingly preferred by panelists.
\end{abstract}

Keywords: celery, formulation, syrup 


\section{PENDAHULUAN}

Hipertensi merupakan salah satu penyakit degeneratif yang harus diwaspadai. Hipertensi menjadi masalah kesehatan masyarakat yang terjadi di negara maju maupun negara berkembang (Depkes RI, 2008). Peningkatan tekanan darah yang berlangsung kronik akan meningkatkan terjadinya resiko penyakit degeneratif lainnya dan kerusakan fungsi organ tubuh, seperti otak, jantung, dan ginjal (Tedjasukmana, 2012).

Berdasarkan Riset Kesehatan Dasar (Riskesdas) Republik Indonesia tahun 2013 melaporkan bahwa prevalensi hipertensi di Indonesia sebesar 26,5\% (Kemenkes RI, 2013). Berdasarkan data sekunder yang diperoleh dari Dinas Kesehatan Kota Kendari, menunjukkan bahwa dari tahun ke tahun jumlah penderita hipertensi di Kota Kendari mengalami peningkatan dan penurunan. Penderita hipertensi pada tahun 2009 sebanyak 4417 kasus, pada tahun 2010 sebanyak 10.173 kasus, pada tahun 2011 sebanyak 10.953 kasus, pada tahun 2014 sebanyak 7727, pada tahun 2015 sebanyak 6743 kasus (Dinkes Kota Kendari, 2015). Seledri tidak memiliki efek samping untuk tubuh kita, mudah didapat dan harganya pun terjangkau untuk semua kalangan (Wahdah dan Nurul, 2011).

Tanaman Seledri merupakan tumbuhan yang memiliki khasiat sebagai bahan obat tradisional yang memiliki efek anti hipertensi, diuretik ringan dan antiseptik pada saluran kemih serta antirematik (Nadinah, 2008). Masruhen (2000),melaporkan bahwa uji pendahuluan tanaman ini mampu menurunkan tekanan darah pada hewan uji. Hasil penelitian yang dilaporkan oleh Asmawati et al., (2015), bahwa pengukuran tekanan darah sistole sebelum diberi perlakuan diperoleh rata-rata (mean) 166,33 mmHg. Hasil pengukuran tekanan darah sistole setelah diberi perlakuan selama 1 minggu diperoleh rata-rata (mean) 146,28 mmHg. Hasil pengukuran tekanan darah diastole sebelum diberi perlakuan diperoleh rata-rata (mean) 98,17 mmHg. Hasil pengukuran tekanan darah diastole setelah diberi perlakuan selama 1 minggu diperoleh rata-rata (mean) 84,50 mmHg. Alamsyah (2017) melaporkan bahwa selisih rata-rata sistole dan diastole setelah pemberian 
jus seledri $39 \mathrm{mmHg}$ dan $22 \mathrm{mmHg}$ Bangsa Purwokerto. Bahan yang sedangkan pada air rebusan didapatkan digunakan dalam penelitian ini adalah selisih hasil $20 \mathrm{mmHg}$ dan $20 \mathrm{mmHg}$ daun seledri yang diperoleh dari pasar dengan $\mathrm{p}$ valuesistole 0,000 dan Wage Purwokerto. Bahan penunjang diastole 0,025. Dewi et al., (2010), berupa etanol $96 \%, \mathrm{CMC}$, asam sitrat, dalam hasil penelitiannya melaporkan esens melon, gula non kalori (pemanis bahwa bahwa ekstrak etanol seledri buatan komersil), dan aquades. dapat menurunkan tekanan darah sistol Analisis mutu dan organoleptik sirup dan diastol. Minuman fungsional ekstrak daun seledri meliputi adalah minuman yang mengandung pengukuran $\mathrm{pH}$ (AOAC, 2005), uji unsur-unsur zat gizi atau non zat gizi, viskositas (Rostia et al., 2014), uji baik dalam bentuk cair, serbuk maupun homogenitas (Gunawan dan tablet, dapat diminum dan memberikan Simaremare, 2016).

efek/pengaruh terhadap satu atau

Pembuatan sirup menggunakan sejumlah terbatas fungsi dalam tubuh metode yang dilaporkan oleh tetapi yang bersifat positif, sehingga Rahmaningtyas (2016), dengan dapat menyehatkan pada tubuh beberapa modifikasi. Ekstrak daun (Muchtadi dan Wijaya, 1996).

Berdasarkan uraian diatas, maka seledri ditimbang sebanyak $0,55 \mathrm{~g}$, $0,65 \mathrm{~g}, 0,85 \mathrm{~g}$, dan $1 \mathrm{~g}$. Setelah itu pengaruh variasi penambahan ekstrak sebanyak 5 g gula non kalori dan asam daun seledri pada pembuatan sirup sitrat $0,2 \mathrm{~g}$ dilarutkan kedalam $50 \mathrm{~mL}$ fungsional dari ekstrak daun seledri air mendidih dan diaduk sampai (Apium graveolens L.) terhadap homogen. Lalu ditambahkan CMC penilaian organoleptik dan mutu 0,33 g sambil diaduk sampai homogen. sediaan sirup dilakukan.

\section{METODOLOGI}

Kemudian didinginkan lalu

Penelitian ini dilaksanakan di Selanjutnya masing-masing Laboratorium Kimia Farmasi, ditambahkan ekstrak seledri lalu Laboratorium Teknologi Farmasi ditambahkan aquades sampai 100\% (60 Program Studi S1 Farmasi Sekolah $\mathrm{mL}$ ), dan diaduk sampai homogen Tinggi Ilmu Kesehatan Harapan selama 20 menit, kemudian disaring 
dengan kain saring hingga diperoleh ekstrak daun seledri, (M2)=0,39\% hasil saringan yang merupakan sirup $(0,65 \mathrm{~g})$ ekstrak daun seledri, dari ekstrak daun seledri. $\quad(\mathrm{M} 3)=0,51 \% \quad(0,85 \mathrm{~g})$ ekstrak daun

Penelitian ini menggunakan seledri dan (M4)=0,6\% (1 g) ekstrak Rancangan Acak Lengkap (RAL) yang daun seledri. Masing-masing terdiri dari 5 jenis perlakuan dan percobaan ditambahkan gula non kalori masing-masing perlakuan diulang $3 \%(5 \mathrm{~g})$, asam sitrat $0,12 \%(0,2 \mathrm{~g})$, sebanyak 3 kali, sehingga diperoleh 15 CMC 0,2\% (0,33 g), essence melon unit percobaan. Adapun perlakuannya $0,18 \%(0,3 \mathrm{~g})$ dan aquades $100 \%$ (60 sebagai berikut: $(\mathrm{M} 0)=0 \%$ ekstrak daun $\mathrm{mL})$.

seledri (kontrol), (M1)=0,33\% (0,55 g)

\section{HASIL DAN PEMBAHASAN}

Hasil rekapitulasi analisis

ragam pengaruh penambahan

ekstrak daun seledri terhadap uji organoleptik (warna, aroma dan rasa) pangan fungsional dalam bentuk sirupdari ekstrak daun seledri disajikan pada Tabel 1.

Tabel 1. Rekapitulasi analisis ragam pengaruh penambahan ekstrak daun se terhadap uji organoleptik (warna, aroma dan rasa) pangan fungsi dalam bentuk sirup dari ekstrak daun seledri.

\begin{tabular}{|c|c|c|c|}
\hline \multirow[b]{2}{*}{$\Lambda$} & & Analisis Ragam & \multirow[b]{2}{*}{ SNI } \\
\hline & Variabel Pengamat & $\begin{array}{c}\text { Pengaruh Konsentrasi Ekstrak Da } \\
\text { Seledri }\end{array}$ & \\
\hline 1. & Warna & tn & Sesuai \\
\hline 2. & Aroma & $* *$ & Sesuai \\
\hline 3. & Rasa & $* *$ & Sesuai \\
\hline
\end{tabular}

Keterangan : tn $=$ berpengaruh tidak nyata, $* *=$ berpengaruh sangat nyata.

Hasil rekapitulasi analisis dilihat pada Tabel 2, menunjukkan ragam pengaruh penambahan ekstrak daun seledri terhadap uji organoleptik parameter yang berpengaruh sangat (warna, aroma dan rasa) pangan nyata adalah aroma dan rasa. fungsional dalam bentuk sirupdari Sedangkan parameter warna ekstrak daun seledri yang dapat 
1. Warna

Berdasarkan hasil analisis ragam organoleptik (warna) sirup yang tersaji pada Tabel 1, menunjukkan hasil yang tidak berpengaruh nyata pada perlakuan M0, M1, M2, M3 dan M4. Warna pada perlakuan M0 memiliki warna hijau yang cerah, sedangkan warna pada perlakuan M1, M2, M3 dan M4 memiliki warna hijau yang agak sedikit tua dengan semakin tingginya konsetrasi ekstrak yang ditambahkan. Hal tersebut diduga dipengaruhi oleh kandungan klorofil yang terdapat pada daun seledri. Sumaenda (2011) melaporkan bahwa klorofil adalah pigmen berwarna hijau yang terdapat dalam kloroplas. Liliana (2011) melaporkan bahwa warna hijau disebabkan karena klorofil pada daun terlarut. Goodman (2008), melaporkan bahwa zat klorofil yang terkandung dalam seledri yaitu 3-nbutylphthalide yang berfungsi merelaksasi dan melemaskan otot-otot halus pembuluh darah dan menurunkan hormon stres dalam darah, sehingga efektif dalam menurunkan darah.

\section{Aroma}

Hasil analisis uji organoleptik untuk parameter aroma disajikan pada Tabel 2.

Tabel 2. Rerata parameter kesukaan aroma pangan fungsional dalam be sirup dari ekstrak daun seledri.

\begin{tabular}{|c|c|c|c|}
\hline Sampe & $\begin{array}{c}\text { Konsentrasi Ekstrak L } \\
\text { Seledri (\%) } \\
\end{array}$ & Rerata Parameter I & Kategori \\
\hline MO & 0 & $4,03 \pm 0.490$ & Suka \\
\hline M1 & 0,33 & $4,03 \pm 0.320$ & Suka \\
\hline M2 & 0,39 & $3,73 \pm 0.583$ & Suka \\
\hline M3 & 0,51 & $3,60 \pm 0.563$ & Agak Suka \\
\hline M4 & 0,6 & $3,23 \pm 0.626$ & Agak Suka \\
\hline
\end{tabular}

Berdasarkan hasil analisis ragam parameter kesukaan aroma yang tersaji organoleptik (aroma) sirup yang terdapat pada Tabel 3, menunjukkan bahwa sampel pada Tabel 2, menunjukkan hasil yang M1 (penambahan 0,33\% ekstrak daun berpengaruh sangat nyata pada perlakuan seledri), memiliki nilai tertinggi dari M0, M1, M2, M3 dan M4. Rerata parameter aroma sampel yang lainnya, 
yaitu dengan nilai sebesar 4,03 (suka). oleh Husen et al., (2015), bahwa Tingginya nilai sampel M1 pada parameter penggunaan essence melon 0,3 g, mampu aroma diduga karena penambahan ekstrak menutupi aroma khas ekstrak yang daun seledri yang sedikit, maka bau digunakan serta memberikan sensasi aroma aromatik seledri tidak begitu kuat dan melon.

tajam, dan menguapnya senyawa volatil pada daun seledri yang cukup banyak saat proses evaporator ekstrak pada suhu $50^{\circ} \mathrm{C}$, serta terciumnya aroma melon pada sampel karena penggunaan essence melon, sehingga sampel M1 cenderung lebih disukai oleh panelis. Seperti yang dilaporkan oleh Saragih (2014), bahwa perubahan aroma karena proses menguapnya senyawa-senyawa volatil, karamelisasi karbohidrat, dekomposisi protein dan lemak serta koagulasi protein yang disebabkan oleh pemanasan. Berdasarkan publikasi BPOM RI (2008), seledri mengandung minyak menguap (senyawa volatil) seperti (+)-limonene, myrcene, $\beta$-selinene, $\alpha$-terpineol, carveol, dihydrocarvone, geranyl acetate, dan senyawa phthalide yang memberikan bau aromatik yaitu 3-butyliden phthalid, 3-butyl phthalid dan 3- isobutyliden dihydrophthalid. Pemberian essence melon juga membantu menutupi aroma khas seledri dari ekstrak yang digunakan, serta memberikan sedikit sensasi aroma buah melon pada sirup. Seperti yang dilaporkan

Sedangkan pada sampel M4 (penambahan 0,6\% ekstrak daun seledri), memiliki nilai terendah dari parameter aroma sampel yang lainnya, yaitu dengan nilai sebesar 3,23 (agak suka). Rendahnya nilai sampel M4 pada parameter aroma diduga karena penambahan ekstrak daun seledri yang semakin banyak, maka bau aromatik seledri semakin kuat dan tajam, sehingga sampel M4 cenderung agak disukai oleh panelis. Seperti yang dilaporkan oleh Palupi dan Widyaningsih (2015), bahwa aroma berhubungan dengan senyawa volatil yang ada pada suatu bahan, dimana semakin banyak komponen volatilnya maka aroma yang dihasilkan pun akan semakin kuat dan tajam.

Aroma pada perlakuan M0 memiliki aroma melon, sedangkan aroma pada perlakuan M1, M2, M3 dan M4 memiliki aroma melon namun memiliki sedikit aroma khas seledri, akan tetapi aroma melon lebih mendominasi. Aroma khas seledri tersebut diduga berasal dari kandungan senyawa pembentuk aroma yang ada pada daun seledri, yaitu apiin. 
Tim Prima Tani (2011), melaporkan dinyatakan "normal".Aroma yang tercium bahwa senyawa Apiin (Apigenin 7- pada pangan fungsional dalam bentuk Apiosiglukosida) adalah glukosida sirup dari ekstrak daun seledri, berasal penghasil aroma daun seledri. dari bahan-bahan pembuatan sirup itu Berdasarkan publikasi SNI 3544 (BSN, sendiri. Sehingga pangan fungsional 2013), aroma sirup yang baik adalah tidak dalam bentuk sirupdari ekstrak daun tercium bau asing, maka hasilnya seledri sesuai dengan SNI.

3. Rasa

Hasil analisis lanjut uji organoleptik untuk parameter rasa disajikan pada Tabel 3.

Tabel 3. Rerata parameter kesukaan rasa pangan fungsional dalam bentuk : dari ekstrak daun seledri.

\begin{tabular}{llll}
\hline \multirow{2}{*}{ Sampe } & $\begin{array}{c}\text { Konsentrasi Ekstrak D } \\
\text { Seledri (\%) }\end{array}$ & Rerata Parameter R & Kategori \\
\hline MO & 0 & $3,73 \pm 0.52$ & Suka \\
M1 & 0,33 & $3,93 \pm 0.45$ & Suka \\
M2 & 0,39 & $3,63 \pm 0.56$ & Suka \\
M3 & 0,51 & $3,30 \pm 0.53$ & Agak Suka \\
M4 & 0,6 & $2,87 \pm 0.57$ & Agak Suka \\
\hline
\end{tabular}

Berdasarkan hasil analisis ragam senyawa tanin tidak begitu kuat dan tajam, organoleptik (rasa) sirup yang terdapat pada serta rasa pahit tersebut telah ditutupi Tabel 2,menunjukkan hasil yang dengan rasa manis dari gula non kalori dan berpengaruh sangat nyata pada perlakuan rasa melon dari essence melon yang M0, M1, M2, M3 dan M4. Rerata digunakan, sehingga sampel M1 cenderung parameter kesukaan rasa yang tersaji pada lebih disukai oleh panelis. Sayuti (2015), Tabel 4, menunjukkan bahwa sampel M1 dalam penelitiannya melaporkan bahwa (penambahan $0,33 \%$ ekstrak daun seledri), memiliki nilai tertinggi dari parameter rasa sampel yang lainnya, yaitu dengan nilai sebesar 3,93 (suka).

Tingginya nilai sampel M1 pada parameter rasa diduga karena penambahan ekstrak yang sedikit, sehingga rasa pahit dari ekstrak daun seledri yang berasal dari penambahan pemanis dapat menutupi rasa pahit getir yang dihasilkan oleh seledri. Pemanis non kalori digunakan pada penelitian ini dengan kandungan sukralosa.

Goldsmith dan Merkel (2001), dan BPOM (2004), melaporkan bahwa sukralosa memiliki rasa manis dengan kemanisan relatif sebesar 600 kali tingkat 
kemanisan gula, tanpa nilai kalori dan tidak memberikan purna rasa yang tidak diinginkan. Sedangkan pada sampel M4 (penambahan $0,6 \%$ ekstrak daun seledri), memiliki nilai terendah dari parameter rasa sampel yang lainnya, yaitu dengan nilai sebesar 2,87 (agak suka). Rendahnya nilai sampel M4 pada parameter rasa diduga karena penambahan ekstrak daun seledri yang semakin banyak, maka rasa pahit seledri semakin kuat, sehingga sampel M4 cenderung agak disukai oleh panelis.Rasa pahit yang ada pada sirup tersebut diduga berasal dari kandungan senyawa tanin yang ada pada daun seledri. Liliana (2011), melaporkan bahwa rasa pahit yang berasal dari daun seledri, disebabkan karena kandungan tanin. Semakin banyak kandungan tanin rasa yang dihasilkan semakin pahit.

Menurut Manitto (1981), senyawa tanin berasa kelat di dalam mulut. Hal ini disebabkan karena pengendapan glikoprotein tertentu yang terdapat di dalam air ludah, yang biasanya mempunyai sifat sebagai pelumas. Nasution (2018), bahwa ekstrak daun seledri positif (+) mengandung senyawa tanin setelah bereaksi dengan larutan FeCL3.Sampel M0, M1 dan M2, memiliki nilai rata-rata kesukaan rasa yang berada dalam kategori yang sama yaitu skala 4 (suka). Namun sampel M3 dan M4 memiliki nilai rata-rata kesukaan rasa yang rendah dibanding sampel lainnya, yaitu berada dalam kategori skala 3 (agak suka). Rasa pada sirup yaitu manis dan rasa melon, namun memiliki sedikit rasa pahit, akan tetapi rasa manis dan rasa melon lebih mendominasi.

Dengan demikian, rasa sirup dari ekstrak daun seledri berasal dari bahan baku sirup tersebut, dimana rasa manis berasal dari gula non kalori, rasa melon berasal dari essence melon dan rasa pahit berasal dari ekstrak daun seledri. Berdasarkan publikasi SNI 3544 (BSN, 2013), rasa sirup yang baik adalah tidak terasa rasa asing, maka hasilnya dinyatakan "normal". Rasa yang terdapat pada pangan fungsional dalam bentuk sirup dari ekstrak daun seledri, berasal dari bahan-bahan pembuatan sirup itu sendiri. Sehingga sirup dari ekstrak daun seledri sesuai dengan persyaratan SNI.

\section{Pengukuran Keasaman ( $\mathrm{pH})$ dan Viskositas}

Hasil rekapitulasi analisis ragam $\mathrm{pH}$ dan viskositas pangan fungsional dalam bentuk sirupdari ekstrak daun seledri disajikan pada Tabel 6. 
Tabel 4. Rekapitulasi analisis ragam $\mathrm{pH}$ dan viskositas pangan fungsi dalam bentuk sirup dari ekstrak sdaun seledri.

\begin{tabular}{|c|c|c|}
\hline \multirow[b]{2}{*}{ No. } & \multirow[b]{2}{*}{ Variabel Pengamatan } & Analisis Ragam \\
\hline & & $\begin{array}{c}\text { Pengaruh Konsentrasi Ekstrak Dau } \\
\text { Seledri }\end{array}$ \\
\hline 1. & pH hari ke-1 & $\operatorname{tn}$ \\
\hline 2. & $\mathrm{pH}$ hari ke-7 & $* *$ \\
\hline 3. & Viskositas & ** \\
\hline
\end{tabular}

Hasil rekapitulasi analisis ragam $\mathrm{pH}$ ekstrak daun seledri menunjukkan hasil dan viskositas sirup dari ekstrak daun yang tidak berpengaruh nyata pada seledri yang dapat dilihat pada Tabel 5, perlakuan M0, M1, M2, M3 dan M4, menunjukkan parameter yang berpengaruh dimana $\mathrm{pH}$ hari pertama masih dalam sangat nyata adalah $\mathrm{pH}$ hari ke-7 . kategori berasam rendah $(\mathrm{pH}>5,3)$. Sedangkan parameter $\mathrm{pH}$ hari ke- 2 ) $\mathrm{pH}$ Hari Ke-7 berpengaruh tidak nyata. Hasil analisis lanjut parameter $\mathrm{pH}$ hari a. $\mathrm{pH}$

1) $\mathrm{pH}$ Hari Ke-1 ketujuh setelah penyimpanan pada suhu $5^{\circ} \mathrm{C}-10^{\circ} \mathrm{C}$ disajikan pada Tabel 6.

Hasil analisis ragam $\mathrm{pH}$ hari pertama pangan fungsional dalam bentuk sirupdari

Tabel 5. Rerata parameter $\mathrm{pH}$ pangan fungsional dalam bentuk sirup ekstrak daun seledri pada hari ketujuh setelah penyimpanan suhu $5^{\circ} \mathrm{C}-10^{\circ} \mathrm{C}$.

\begin{tabular}{|c|c|c|c|}
\hline Sampe & $\begin{array}{c}\text { Konsentrasi Ekstrak Da } \\
\text { Seledri }(\%)\end{array}$ & $\frac{\text { Rerata }}{\text { pH Hari Ke-7 }}$ & Kategori \\
\hline M0 & 0 & $4,36 \mathrm{a} \pm 0,03$ & Asam \\
\hline M1 & 0,33 & $4,49 a \pm 0,12$ & Asam \\
\hline M2 & 0,39 & $4,14 b \pm 0,08$ & Asam \\
\hline M3 & 0,51 & $4,19 b \pm 0,11$ & Asam \\
\hline M4 & 0,6 & $4,14 b \pm 0,10$ & Asam \\
\hline
\end{tabular}

Keterangan : Angka-angka yang diikuti oleh huruf yang berbeda pada kolom yang sama berbeda nyata pada taraf kepercayaan $95 \%$. 
Berdasarkan hasil analisis ragam pH Shaw, (1990), melaporkan bahwa sirup hari ke-7 yang tersaji pada Tabel penurunan nilai $\mathrm{pH}$ dipengaruhi oleh 5 ,menunjukkan hasil yang berpengaruh kandungan asam organik. Hasil penelitian sangat nyata pada perlakuan M0, M1, M2, ini sejalan dengan penelitian yang M3 dan M4. Rerata parameter pH sirup hari dilaporkan oleh Fardiaz (1992), yang ke-7 yang tersaji pada Tabel 6, menyatakan bahwa $\mathrm{pH}$ makanan dan menunjukkan bahwa pH sampel M1 masih minuman dipengaruhi oleh kandungan asam dalam kategori asam yaitu $\mathrm{pH} 4,49$, namun yang terdapat pada bahan pangan. Menurut tidak lebih asam dari sampel yang lainnya. teori Archenius, semakin banyak ion $\mathrm{H}+$ Hal tersebut diduga karena kandungan asam maka semakin besar konsentrasi $\mathrm{H}+$ organik yang terdapat pada daun seledri sehingga $\mathrm{pH}$ semakin rendah (Anjani, tidak terlalu banyak. Anjani (2003), 2003). Selain itu, Daroini (2006), melaporkan bahwa salah satu faktor yang melaporkan bahwa penurunan $\mathrm{pH}$ mempengaruhi tingkat keasaman adalah disebabkan oleh terbentuknya asam pada kadar total asam pada bahan. Hasil produk yang dihasilkan oleh aktivitas penguraian asam-asam organik pada bahan mikroba serta adanya kandungan pati atau pangan adalah $\mathrm{CO} 2$ dan $\mathrm{H} 2 \mathrm{O}$, sehingga gula dalam bahan. Adanya kandungan pati konsentrasi $\mathrm{H}+$ (berasal dari asam organik) dan gula pereduksi dalam sirup diduga menjadi berkurang. Berkurangnya dapat menurunkan nilai pH. Dalimartha konsentrasi ion $\mathrm{H}+$ menyebabkan pH naik. (2000), melaporkan bahwa kandungan Sedangkan pada sampel M2 (penambahan karbohidrat dalam daun seledri per $100 \mathrm{~g}$ 0,39\% ekstrak daun seledri) dan M4 adalah sebesar 4 g. Maka dari itu, selain (penambahan 0,6\% ekstrak daun seledri), kandungan asam-asam organik pada sirup, menunjukkan $\mathrm{pH}$ sampel masih dalam diduga penurunan nilai keasaman pada kategori asam yaitu $\mathrm{pH}$ 4,14, namun sirup juga diakibatkan adanya kandungan memiliki rasa yang lebih asam dari sampel pati dalam ekstrak daun seledri yang M1. Hal tersebut diduga karena semakin digunakan. Meskipun begitu, semua $\mathrm{pH}$ banyak konsetrasi ekstrak yang digunakan, sirup hari ke-7 masih memenuhi maka semakin banyak pula kandungan persyaratan SNI 01-2891, yaitu antara 3,5 asam organik yang terdapat pada ekstrak 4 (BSN, 1992). Bahan pangan dapat serta adnya aktivitas mikroba. Nagy dan digolongkan atas beberapa kelompok 
berdasarkan $\mathrm{pH}$ nya yaitu bahan pangan bahan pangan tersebut. Semakin rendah berasam rendah $(\mathrm{pH}>5,3)$, sedang $(\mathrm{pH} 4,5-\quad \mathrm{ppH}$ semakin kurang perlakuan pengawetan $5,3)$, asam ( $\mathrm{pH} 3,7-4,5)$, tinggi $(\mathrm{pH}<3,7)$. yang harus diberikan kepada bahan pangan Hal ini terkait dengan daya awet suatu tersebut.

b. Analisis Viskositas

Hasil analisis lanjut uji viskositas disajikan pada Tabel 6.

Tabel 6. Rerata parameter viskositas pangan fungsional dalam be sirup dari ekstrak daun seledri.

\begin{tabular}{|c|c|c|c|}
\hline Sampel & $\begin{array}{c}\text { Konsentrasi Ekstr } \\
\text { Daun Seledri }\end{array}$ & $\frac{\text { Rerata }}{\text { Viskositas (cP) }}$ & Kategori \\
\hline M0 & 0 & $0,27 b \pm 0,02$ & Kental \\
\hline M1 & 0,33 & $0,30 \mathrm{~b} \pm 0,02$ & Kental \\
\hline M2 & 0,39 & $0,27 b \pm 0,01$ & Kental \\
\hline M3 & 0,51 & $0,26 b \pm 0,01$ & Kental \\
\hline M4 & 0,6 & $0,37 \mathrm{a} \pm 0,05$ & Kental \\
\hline
\end{tabular}

Keterangan : Angka-angka yang diikuti oleh huruf yang berbeda pada kolom yang sama berbeda nyata pada taraf kepercayaan $95 \%$.

Berdasarkan hasil analisis ragam viskositas sirup yang tersaji pada Tabel 5, menunjukkan hasil yang berpengaruh sangat nyata pada perlakuan M0, M1, M2, M3 dan M4. Rerata hasil penelitian yang tersaji pada Tabel 7, menunjukkan bahwa sampel M4 (penambahan 0,6\% ekstrak daun seledri), memiliki nilai rata-rata viskositas lebih tinggi dibandingkan dengan yang lainnya, dengan nilai viskositas sebesar 0.37 cP. Pada sampel M1 (penambahan 0,33\% ekstrak daun seledri), sampel M2 (penambahan 0,39\% ekstrak daun seledri) dan sampel M3 (penambahan
0,51\% ekstrak daun seledri), mengalami penurunan viskositas. Apriani et al., (2013), melaporkan bahwa viskositas tergantung pada kadar air dan suhu. Kadar air yang tinggi maka akan mengalir dengan kecepatan yang lebih tinggi dibandingkan dengan kadar air yang lebih rendah. Berdasarkan laporan penelitian tersebut, diduga sampel yang diuji mengalami peningkatan kadar air selama penyimpanan pada suhu $\quad 5^{\circ} \mathrm{C}-10^{\circ} \mathrm{C}$, dikarenakan kemasan/tutup botol yang digunakan tidak vakum (masih terdapat udara dalam kemasan) dan tidak press, sehingga kelembaban udara (RH) sekitar, memungkinkan air dapat masuk ke dalam kemasan dan ditambah lagi masih terdapatnya udara di dalam kemasan, maka 
setelah penyimpanan, udara yang jenuh serta takanan yang ada di sekitar sampel. dalam kemasan mengalami kondensasi Seperti yang dilaporkan oleh Hangar (berubah menjadi uap air) dan menempel (2007), dalam Syahputra dan Suhartini pada kemasan. Uap air tersebut jatuh ke (2013), bahwa pada pengujian viskositas dalam bahan dan mengakibatkan dipengaruhi oleh perubahan suhu dan peningkatan kadar air yang berdampak pada tekanan, apabila suhu panas meningkat, penurunan viskositas. Sedangkan pada maka viskositasnya akan menurun, begitu sampel M4 (penambahan $0,6 \%$ ekstrak juga sebaliknya apabila suhu panas daun seledri) mengalami peningkatan menurun, maka viskositasnya akan diduga karena perubahan suhu ruang yang meningkat. Viskositas juga akan meningkat tidak stabil pada saat setelah penyimpanan, seiring meningkatnya tekanan.

5. Analisis Homogenitas

Hasil uji homogenitas sirup disajikan pada Tabel 7.

Tabel 7. Hasil Uji homogenitas pangan fungsional dalam bentuk sirup ekstrak daun seledri (Suhu Penyimpanan $5^{\circ} \mathrm{C}-10^{\circ} \mathrm{C}$ )

\begin{tabular}{|c|c|c|c|c|c|}
\hline \multirow{2}{*}{ Sampe } & \multirow{2}{*}{$\begin{array}{c}\text { Konsentrasi Ekstr } \\
\text { Daun Seledri (\% }\end{array}$} & \multirow{2}{*}{ Ulanga } & \multirow{2}{*}{ Jumlah } & \multicolumn{2}{|c|}{ Endapan/Gumpalan } \\
\hline & & & & Hari ke- & Hari ke-' \\
\hline \multirow[t]{3}{*}{ M0 } & 0 & 1 & 10 & - & - \\
\hline & & 2 & 10 & & \\
\hline & & 3 & 10 & & \\
\hline \multirow[t]{3}{*}{ M1 } & 0,33 & 1 & 10 & - & - \\
\hline & & 2 & 10 & & \\
\hline & & 3 & 10 & & \\
\hline \multirow[t]{3}{*}{ M2 } & 0,39 & 1 & 10 & - & - \\
\hline & & 2 & 10 & & \\
\hline & & 3 & 10 & & \\
\hline \multirow[t]{3}{*}{ M3 } & 0,51 & 1 & 10 & - & - \\
\hline & & 2 & 10 & & \\
\hline & & 3 & 10 & & \\
\hline \multirow[t]{3}{*}{ M4 } & 0,6 & 1 & 10 & - & - \\
\hline & & 2 & 10 & & \\
\hline & & 3 & 10 & & \\
\hline
\end{tabular}

Keterangan : tanda (-) menyatakan bahwa sampel tidak memiliki endapan/gumpalan.

Berdasarkan hasil uji homogenitas sirup dari ekstrak daun seledri yang dapat dilihat pada Tabel 7, menunjukkan semua sampel yang diuji negatif (-) memiliki endapan/gumpalan dan hal tersebut menandakan sirup homogen. 
Hasil ini serupa dengan hasil penelitian yang dilaporkan oleh Gunawan dan Simaremare (2016), bahwa sediaan sirup yang dihasilkan homogen, terlihat dari tidak ada endapan pada sirup.

\section{KESIMPULAN}

Penambahan ekstrak daun seledri menunjukkan hasil yang berpengaruh sangat nyata pada uji organoleptik parameter aroma dan rasa. Namun penambahan ekstrak daun seledri menunjukkan hasil berpengaruh tidak nyata terhadap parameter warna sirup dari ekstrak daun seledri. Penambahan ekstrak daun seledri terhadap sirup daun seledri, berpengaruh tidak nyata terhadap uji keasaman $(\mathrm{pH})$ hari pertama setelah penyimpanan pada suhu $5^{\circ} \mathrm{C}-10^{\circ} \mathrm{C}$ dan berpengaruh sangat nyata terhadap pengujian keasaman $(\mathrm{pH})$ pada hari ketujuh setelah penyimpanan pada suhu $5^{\circ} \mathrm{C}-10^{\circ} \mathrm{C}$. Begitupun pada pengujian viskositas sirup yang berpengaruh sangat nyata.

\section{SARAN}

Perlu dilakukan penelitian lebih tentang jenis senyawa aktif flavonoid yang berperan sebagai diuretika.

\section{DAFTAR PUSTAKA}

Ashari, S. 1995. Hortikultura, Aspek Budidaya. Universitas Indonesia. Jakarta
Asmawati, N., Purwati P. dan HandayaniR. S.2015. Efektivitas Rebusan Seledri Dalam Menurunkan Tekanan Darah Pada Lansia Penderita Hipertensi Di Posyandu Lansia Kelurahan Pajar Bulan Kecamatan Way Tenong Lampung Barat. Jurnal Kesehatan. 4 (2): 130-136.

Badan Pengawas Obat dan Makanan Repoblik Indonesia. 2004. Volume I. BPOM RI. Jakarta.

Badan Pengawas Obat dan Makanan Repoblik Indonesia. 2008. Seledri sebagai Bahan Obat Alam.

Badan Standarisasi Nasional. 1992. SNI 012891-1992. Cara Uji Makanan dan Minuman. Jakarta.

Badan Standarisasi Nasional. 2013. SNI 013544: 2013. Sirup. Jakarta.

Dalimartha, S. 2000. Atlas Tumbuhan ObatIndonesia. Jilid II. PT. Trubus Agriwidya. Jakarta.

Departemen Kesehatan Republik Indonesia. 2008. Materia Medika Indonesia. Cetakan Kelima. Departemen Kesehatan Republik Indonesia. Jakarta.

Djamil, R. dan Wijiastuti E. 2015. Penapisan Fitokimia, Uji Aktivita sekstrak Metanol Herba Seledri, Batang/Daun Ashitaba dan Daun Petroseli (Apiaceae). Dipresentasikan pada rakernas \& PITI AI Universitas Pancasila.Jakarta.

Goldsmith, L. A. dan MerkelC. M. 2001. Sucralose. Di dalam: Nabors LOB, 
editor. Alternative Sweetener, Ed ke-3, New York.

$\begin{array}{ccr}\text { Goodman, G. } & 2008 . & \text { The } \\ \text { Pharmacological } & \text { Basis } & \text { and } \\ \text { Therapeutics. Penerbit } & \text { Buku } \\ \text { Kedokteran EGC. Bandung. } & \end{array}$

Gunawan, E. dan Simaremare E. S. 2016. Formulasi Sirup Antimalaria Ekstrak Kulit Batang Kayu Susu (Alstonia Scholaris L.) jurnal Pharmacy. 13 (1): 1-9.

Husen, R. W. M., Yamlean P. V. Y. dan Citraningtyas G. 2015. Formulasi Dan Evaluasi Sirup Ekstrak Daun Sidaguri (Sida rhombifolia L.). Pharmacon jurnal Ilmiah Farmasi Unsrat. 4 (3): 134-138.

Kementerian Kesehatan Republik Indonesia. 2013. Riset Kesehatan Dasar. Badan Penelitian dan Pengembangan Kesehatan. Jakarta.

Liliana,W. 2011. Kajian Pembuatan Teh Herbal dari Seledri (Apium graveolens L.). Skripsi. Fakultas Pertanian. IPB. Bogor.

Manitto, P. 1981. Biosynthesis of Natural Products. Ellis Horwood Limited Publisher, Chicester, Ingris.

Masruhen. 2000. Perbandingan Kadar Flavonoid dan Daya Antihipertensi Antara Sari Etanol 50\% Daun Seledri (Apium graveolens L) Dan Biji Seledri Terhadap Tekanan Darah Sistemik Kucing Dianastesi. Skripsi. Fakultas Farmasi. UGM. Yogyakarta.
Muchtadi, D. dan Wijaya, C. H. 1996. Makanan Fungsional: Pengenalan dan Perancangan. Hand-Out Kursus Singkat Makanan Fungsional dan Keamanan Pangan. PAU Pangan dan Gizi. UGM. Yogyakarta.

Nadinah. 2008. Kinetika Inhibisi Ekstrak Etanol Seledri (Apium graveolens L.) dan Fraksinya Terhadap Enzim Xantin Oksidase Serta Penentuan Senyawa Aktifnya. Tesis. Sekolah Pascasarjana, IPB. Bogor.

Palupi, M. R. dan Widyaningsih, T. D. 2015. Pembuatan Minuman Fungsional Liang Teh Daun Salam (Eugenia polyantha) dengan Penambahan Filtrat Jahe dan Filtrat Kayu Secang. Jurnal Pangan dan Agroindustri.. 3(4): 1458-1464.

Rosita, I. I., Munisa,A. N., Kalsum, A.U. dan Rahmawati, A. 2014. Praktikum Kimia Fisika II Viskositas. Universitas Islam Negeri Syarif Hidayatullah.Jakarta.

Saragih, R. 2014. Uji Kesukaan Panelis Pada Teh Daun Torbagun. E-Jurnal Widya Kesehatan dan Lingkungan. 1 (1): 46-52.

Sayuti, N. A. 2015. Respon rasa campuran ekstrak seledri (Apium graveolens L.) dan ekstrak asam jawa (Tamarindus indica) dalam sediaan serbuk effervescent. Jurnal farmasi indonesia. 12 (2): 114-126.

Siswandono dan Soekardjo, B., 2000, Kimia Medisinal, Edisi 2, 228-232, 234, 239, Airlangga University Press, Surabaya.

Soewito. 1991. Bercocok Tanam Seledri. Titik Terang. Jakarta. 
Sumaenda, L. (2011). Analisis Kandungan

Klorofil Daun Mangga (Mangifera

Indica L.) Pada Tingkat

Perkembangan Daun Yang Berbeda.

Bioslogos. 1 (1): 20-24.

Syahputra, A. R. dan Suhartini M. 2013.

Peningkatkan Stabilitas Viskositas

Pelumas Hidrolik Dari Kopolimer

Lateks Karet Alam-Stirena.

Bionatura-Jurnal Ilmu-ilmu Hayati dan Fisik. 15 (1):60-64.

Syamsuhidayat dan Hutapea, J.R., 1991, Inventaris Tanaman Obat Indonesia, 305-306, Departemen Kesehatan Republik Indonesia, Badan Penelitian dan Pengembangan Kesehatan, Jakarata.

Tedjasukmana, P. 2012. Tata Laksana Hipertensi Departemen Kardiologi, RS Premier Jatinegara dan RS Grha Kedoya. Jakarta. Indonesia.

Tim Prima Tani. 2011. Petunjuk Teknis Budidaya Seledri. Balai Penelitian Tanaman Sayuran. Bandung.

Tiwari, P., Kumar B., Kaur M., Kaur G. \& Kaur H. (2011). A review: Phytochemical Screening and Extraction. Internationale Pharmaceutica Sciencia, 1(1): 98-106.

Wahdah dan Nurul. 2011. Menaklukkan Hipertensid an Diabetes (Mendeteksi, Mencegah dan Mengobati Dengan Cara Medis dan Herbal). Multi Press, Yogyakarta. 